Original Article

\title{
BIOASSAY-GUIDED EVALUATION OF FICUS SEMICORDATA FOR ANTIDIABETIC ACTIVITY
}

\author{
VIRENDER KAUR ${ }^{1 *}$, KUMUD UPADHYAYA ${ }^{2}$, MILIND PANDE $^{3}$
}

${ }^{1,3}$ NIMS Institute of Pharmacy, NIMS University, Shobha Nagar, Jaipur-Delhi Highway, Jaipur, Rajasthan, India, 303121, ${ }^{2}$ Department of Pharmaceutical Sciences, Kumaun University, Bhimtal Campus, Nainital, Uttarakhand, India, 263136

Email: verumalwa@gmail.com

Received: 01 Dec 2016 Revised and Accepted: 09 Jan 2017

\section{ABSTRACT}

Objective: The early stage of diabetes mellitus type 2 is associated with postprandial hyperglycemia. The therapeutic approach involved in the treatment of type 2 diabetes mellitus is the use of agents that can decrease postprandial hyperglycemia by inhibiting carbohydrate digesting enzymes. In an effort of identifying herbal drugs which may become useful in the prevention or mitigation of diabetes, the antidiabetic activity of Ficus semicordata (FS) and its constituents were studied. The present study was undertaken in part to identify the potent antihyperglycemic fraction from the ethanol extract of the plant, using bioassay guided evaluation.

Methods: The ethanol extract of Ficus semicordata were fractionated to obtain chloroform, ethyl acetate, n-butanol and ethanol extracts which were tested for alpha-amylase, alpha-glucosidase inhibitory, properties. Further fractionation of the more active ethanol fraction yielded isolates FS-1 and FS-2 which were tested for in vivo antidiabetic activity using Streptozotocin (STZ)-induced diabetic rats.

Results: Ethanol extract from leaves of the plant showed notable alpha-amylase $\left(\mathrm{IC}_{50}=3.352 \mu \mathrm{g} / \mathrm{ml}\right.$ and alpha-glycosidase inhibitory activity $\left(\mathrm{IC}_{50}=\right.$ $3.448 \mu \mathrm{g} / \mathrm{ml}$ ) as compared to standard acarbose $\left(\mathrm{IC}_{50}=3.175 \mu \mathrm{g} / \mathrm{ml}\right.$. Subfraction FS-1 and FS-2 which were tested for in vivo antidiabetic activity using acute STZ-induced diabetic rats significantly $\left({ }^{*} \mathrm{p}<0.05,{ }^{* *} \mathrm{p}<0.01,{ }^{* * *} \mathrm{p}<0.001\right)$ reduced blood glucose level.

Conclusion: The Ficus semicordata plant extracts and the fractionated components could be used as a natural antidiabetic after comprehensive in vitro and in vivo biological studies.

Keywords: Ficus semicordata, Bioassay-guided evaluation, Alpha-amylase, Alpha-glucosidase inhibitory, Postprandial hyperglycemia, and STZinduced diabetes

(C) 2016 The Authors. Published by Innovare Academic Sciences Pvt Ltd. This is an open access article under the CC BY license (http://creativecommons.org/licenses/by/4. 0/) DOI: http://dx.doi.org/10.22159/ijpps.2017v9i3.16441

\section{INTRODUCTION}

The usage of medicinal plants for treatment of diabetes is since prehistoric time worldwide. The ethnopharmacological studies of traditional herbal remedies used for diabetes around the world have identified more than 1200 species of plants with hypoglycemic activity [1]. Despite the recommendations given by World Health Organization for proper scientific validation, there is a continuous usage of plants in traditional healing system. Medicinal plants are gaining popularity due to minimum side effects, inexpensive and safe when compared to allopathic drugs [2, 3]. Ficus semicordata is a small or medium-sized evergreen or sub-deciduous tree locally known as khaina or khunia [4]. The parts of FS that were used for medicinal treatments are young fruits, bark, leaves used for combating diseases like leprosy, fever $[5,6]$ diarrhea [7] ulcer $[8,9$, 10] gastric problems [11].

Different ethnic communities of Northeast India like Assam, Arunachal Pradesh, Manipur, Mizoram, Tripura, and Nagaland of India are using decoction prepared from the bark of Ficus semicordata to cure diabetes [12]. To scientifically validate this claim and to develop an herbal drug remedy the present study aims to investigate the bioactive guided fractions of FS leaves for antidiabetic activity using both in-vitro and in vivo models.

The present study was undertaken to evaluate in vitro alphaamylase, in vitro alpha-glucosidase activities of crude ethanol extract and its fractions, isolation of most active fractions and in vivo antidiabetic study carried out in streptozotocin (STZ)-induced diabetic rats.

\section{MATERIALS AND METHODS}

\section{Chemicals}

Streptozotocin was purchased from Sieco research laboratories, Mumbai, India. Also, $\alpha$-amylase was purchased from Molychem laboratory reagents and fine chemicals, Mumbai, India, $\alpha$ glucosidase (maltase) was purchased from Sieco research laboratories, Mumbai, India, 4-nitrophenyl- $\alpha$-d-glucopyranoside was purchased from Himedia laboratories, Mumbai, India. Other chemicals were of the highest analytical grade and were purchased from common sources.

\section{Plant material}

The leaves of Ficus semicordata were collected from Bhimtal region (Uttarakhand) in the month of April 2015 and was identified and authenticated by Dr. K. S. Negi, Principal Scientist, National Bureau of Plant Genetic Resources Regional Station, (N. B. P. G. R) Niglat, Bhowali, Uttarakhand. The specimen has been deposited in the herbarium at N. B. P. G. R. Niglat, Bhowali, Uttarakhand with herbarium specimen number VK-04.

\section{Extract preparation}

The leaves of Ficus semicordata were shade dried, crushed and a coarse powder was made using a mechanical grinder. The dried powdered leaves of Ficus semicordata (2.5 kg) after defatting with petroleum ether was subjected to hot continuous extraction with ethanol using soxhlet apparatus till solvent became colourless. Solvent-solvent fractionation of ethanol extract was done using different solvents. The ethanol residue was dissolved in distilled water and the aqueous filtrate was successively extracted with chloroform followed with ethyl acetate and finally with n-butanol. The combined n-butanol, chloroform, ethyl acetate and ethanol fractions were separately concentrated using rotary evaporator. The percentage yield of chloroform extract was $4.63 \%$, ethyl acetate $6.35 \%$, n-butanol $9.51 \%$, ethanol $16.6 \%$. The ethanol fraction was found to be most active fraction based on in vitro antidiabetic studies. Preliminary phytochemical screening and the column chromatography of ethanol extract using solvent system (n-hexane: dichloromethane: ethyl acetate: methanol) (7:1:1:1) revealed the 
presence of many compounds of phenolic and flavonoid components. Therefore the ethanol extract was subjected to chromatographic isolation.

\section{Separation and isolations of chemical constituents from leaves of Ficus semicordata}

Silica gel (60-120 mesh) was used as an adsorbent for column chromatography. The column was taken and packed with cotton at the bottom of the column. The slurry was prepared by silica gel and n-hexane was used as a solvent for free flowing consistency. It was poured slowly from the top of the column in little quantity allowing for even and uniform packing. The 2/3rd of the column was packed by using above procedure. Four ( $4 \mathrm{~g}$ ) grams of the ethanol fraction was pre-adsorbed onto silica gel adsorbent (60-120 mesh) by firstly solubilizing it in a little quantity of ethanol, followed by addition of the silica gel ( $3 \mathrm{~g}$ ) then mixing. The dried fraction-adsorbent mixture was then evenly loaded onto the top of the already packed column. The column was first eluted with $2 \times 300 \mathrm{ml} 100 \% \mathrm{n}$-hexane followed successively by $2 \times 300 \mathrm{ml}$ n-hexane: dichloromethane in graded ratios (9:1), (8:2), (7:3), (6:4), (5:5), (4:6), (3:7), (2:8), (1:9) and finally $(0: 10)$, dichloromethane: ethyl acetate, ethyl acetate: methanol. The fractions collected in the conical flask were marked. The marked fractions were subjected to thin layer chromatography in order to check the homogeneity of various fractions (having same $\mathrm{R}_{\mathrm{f}}$ values). The fractions having same $\mathrm{R}_{\mathrm{f}}$ values were combined together and concentrated. Elution of column with n-hexane: dichloromethane (8:2) fraction no. F3, F4 was obtained as a yellow powder that after recrystallization with methanol formed a yellow amorphous powder. Elution of column with ethyl acetate: methanol (9:1) fraction no. F-11-F-12 was obtained as a white powder that after recrystallization with methanol formed a white amorphous powder. The resultant isolated compounds were tested for antidiabetic activity in vivo. The isolates were characterised by spectroscopy techniques like IR, $\mathrm{H}^{1} \mathrm{NMR}$, and Mass spectrum.

\section{In vitro antidiabetic activity}

\section{Alpha-amylase enzyme inhibition assay}

A total of $500 \mu \mathrm{l}$ of test samples and standard drug (100-1000 $\mu \mathrm{g} / \mathrm{ml}$ ) were added to $500 \mu \mathrm{l}$ of $0.20 \mathrm{mmol}$ phosphate buffer $(\mathrm{pH}$ 6.9) containing alpha amylase $(0.5 \mathrm{mg} / \mathrm{ml})$ solution and were incubated at $25{ }^{\circ} \mathrm{C}$ for $10 \mathrm{~min}$. after these, $500 \mu \mathrm{l}$ of $1 \%$ starch solution in $0.02 \mathrm{M}$ sodium phosphate buffer $(\mathrm{pH} 6.9$ ) was added to each tube. The reaction mixtures were then incubated at $25^{\circ} \mathrm{C}$ for 10 min. The reaction was stopped with $1.0 \mathrm{ml}$ of 3, 5 dinitro salicylic acid colour reagent. The test tubes were then incubated in a boiling water bath for $5 \mathrm{~min}$, cooled to room temperature. The reaction mixture was then diluted after adding $10 \mathrm{ml}$ distilled water and absorbance was measured at $540 \mathrm{~nm}$. Control represented 100\% enzyme activity and was conducted in a similar way by replacing extract with the vehicle. Acarbose was used as a positive control [13]. The experiments were repeated thrice and the \% inhibition in the alpha-glucosidase by the test sample or acarbose was calculated by the following equation:

$$
\begin{gathered}
\% \text { inhibition }=[100-((\text { Abs sample }]-\text { Abs blank }) \\
\times 100)] \text { Abs blank }
\end{gathered}
$$

\section{Calculation of $\mathrm{IC}_{50}$}

The concentration of the extract that inhibits 50\% of the enzyme activity $\left(\mathrm{IC}_{50}\right)$ was calculated. Extracts with high inhibitory activity were analyzed using a series of suitable extract concentrations. $\mathrm{IC}_{50}$ values were determined by plotting percent inhibition ( $\mathrm{Y}$ axis) versus $\log _{10}$ extract concentration (X axis) and calculated by logarithmic regression analysis from the mean inhibitory values [14].

\section{Alpha-glucosidases enzyme inhibition assay}

$\alpha$-glucosidase inhibitory activity in the submitted samples was performed according to the method as described (Pistia Brueggeman and Hollingsworth, 2001). The assay mixture contained $500 \mu \mathrm{l}$ of phosphate buffer ( $50 \mathrm{mmol}$; $\mathrm{pH} 6.8$ ), $100 \mu \mathrm{l}$ of purified alpha-glucosidase $(1 \mathrm{U} / \mathrm{ml}), 185 \mu \mathrm{l}$ of TDW and $10 \mu \mathrm{M}$ of the desired sample. The assay mixture was pre-incubated for $10 \mathrm{~min}$ at $37^{\circ} \mathrm{C}$ and then $100 \mu \mathrm{l}$ of glutathione $(1 \mathrm{mg} / \mathrm{ml})$ and $100 \mu \mathrm{l}$ of $1 \mathrm{mmol}$ PNPG were added to the assay mixture as substrates. After further incubation at $37^{\circ} \mathrm{C}$ for $20 \mathrm{~min}$, the reaction was stopped by adding $500 \mu \mathrm{l}$ of $\mathrm{Na}_{2} \mathrm{CO}_{3}$ $(0.1 \mathrm{M})$ and the yellow color formed of p-nitrophenol was read at 405 $\mathrm{nm}$ in a spectrophotometer. The purified enzyme and substrate solutions were prepared in the same buffer. Acarbose was used as a positive control [15]. The experiments were repeated thrice, and the $\%$ inhibition in the alpha-glucosidase by the test sample or acarbose was calculated by the following equation:

$$
\begin{aligned}
\% \text { inhibition } & =[100-((\text { Abs sample }]-\text { Abs blank }) \\
& \times 100)] \text { Abs blank }
\end{aligned}
$$

\section{Calculation of IC 50}

The concentration of the extract that inhibits 50\% of the enzyme activity $\left(\mathrm{IC}_{50}\right)$ was calculated. Extracts with high inhibitory activity were analyzed using a series of suitable extract concentrations. $\mathrm{IC}_{50}$ values were determined by plotting percent inhibition ( $\mathrm{Y}$ axis) versus $\log _{10}$ extract concentration (X axis) and calculated by logarithmic regression analysis from the mean inhibitory values [14].

\section{In vivo antidiabetic activity}

\section{Experimental animals}

Healthy Wistar albino rats (150-250 g body weight each) maintained on standard laboratory diet and aqua water ad libitum were employed in the present study. They were housed in department animal house $12 \mathrm{~h}$ light and $12 \mathrm{~h}$ dark cycle. The animals were acclimatized to laboratory conditions for one $\mathrm{w}$ before the commencement of the experiment. The study was approved by institutional ethics committee from Department of Pharmaceutical Sciences, Kumaun University, Bhimtal campus, Nainital, India (Regd. No. KUDOPS/23).

\section{Acute toxicity study}

An acute toxicity study was carried to check the toxic effects of the isolates FS-1, FS-2. The study was performed as per Organization for Economic Cooperation and Development (OECD) guidelines no. 423. Healthy Wistar albino rats $(n=6)$ of either sex selected by random sampling were used for acute toxicity study. The animals were fasted overnight and provided only with water, after that the extract was administered orally at $5 \mathrm{mg} / \mathrm{kg}$ body weight by gastric intubation and observed for $14 \mathrm{~d}$. If mortality was observed in two out of three animals, then the dose administered was assigned as a toxic dose. If mortality was observed in one animal, then the same dose was repeated again to confirm the toxic dose. If mortality was not observed, the procedure was repeated for higher doses such as 50,100 up to $2000 \mathrm{mg} / \mathrm{kg}$ body weight [15].

\section{Induction of diabetes}

Diabetes was induced in each group using a freshly prepared solution of streptozotocin (STZ). STZ solution was prepared freshly in ice-cold citrate buffer $(0.1 \mathrm{M}, \mathrm{pH} 4.5)$. For inducing diabetes, the rats were kept on fasting for $18 \mathrm{~h}$ and diabetes was induced by giving a single i. p. injection of STZ (30 mg/kg b.w.) following the standard methodology of the intraperitoneal route of drug administration. After six h of STZ injection, the rats were supplied with $20 \%$ glucose solution in water bottles for next $24 \mathrm{~h}$. The fasting blood glucose level of the rats was measured after $72 \mathrm{~h}$. The rats having fasting blood glucose level above $200 \mathrm{mg} / \mathrm{dl}$ were selected for further experimentation [16].

\section{Collection of blood and determination of blood glucose levels}

Blood was collected on the 1 st d, i.e., the don which the dosing was started, 7th d, 14th d and 21st d through puncture tail vein and collected blood samples were analyzed using glucose oxidaseperoxidase reactive strips and Accu-check Glucometer. Blood glucose levels were expressed in terms of $\mathrm{mg} / \mathrm{dl}$ [18].

\section{Experimental protocol}

Healthy Wistar strain albino rats were selected and randomly divided into five groups with six animals in each group. They were grouped as: 
Group I-Normal, receiving $1 \mathrm{ml}$ of normal saline orally.

Group II-Diabetic control, receiving $1 \mathrm{ml}$ of $2 \%$ gum acacia suspension orally.

Group III-Diabetic group, receiving $50 \mathrm{mg} / \mathrm{kg}$ b.w. of FS-1 orally.

Group IV-Diabetic group, receiving $50 \mathrm{mg} / \mathrm{kg}$ b.w. of FS-2 orally.

Group-V Standard drug, receiving glibenclamide, $30 \mathrm{mg} / \mathrm{kg}$ b.w. orally.

These animals received their doses by oral route using an oral gastric tube. All the groups were given respective treatments daily for $21 \mathrm{~d}[18,19,20$, and 21].

\section{Estimation of other physiological parameters}

Physiological parameters like food and fluid intake, urine excretion and body weight were monitored during the experimentation. In order to check the effect of the isolated compound FS-1, FS-2 on the weight, the weight of the rats was recorded prior to the administration of the compounds and at 1st, 7th, 14th d and at the end of the study i.e. on the 21st d. The urine volume may not be measured instead an overview was made by the wetting of cage bedding by urine. The initial and final amount of feed provided to rats in the cages was weighed and the average food intake value was calculated. Similarly, the average fluid intake was determined by measuring the initial and final volume of water.

\section{Statistical analysis}

All the values of fasting blood glucose level, body weight, and physiological parameters were expressed as mean \pm standard error of the mean (SEM) and analyzed for Newman Keul's test significantly different at $\left({ }^{*} \mathrm{p}<0.05,{ }^{* *} \mathrm{p}<0.01,{ }^{* * *} \mathrm{p}<0.001\right)$ when compared with diabetic control group.

\section{RESULTS}

\section{Screening for in vitro antidiabetic activity}

The separated extracts from the plant FS was screened for its capacity to inhibit alpha-amylase, alpha-glucosidase enzymes. The observed inhibitions are shown in Fig.1, 2. The $\mathrm{IC}_{50}$ value of alphaamylase and $\alpha$-glucosidase inhibitory activity of various extracts of Ficus semicordata are shown in table 1.

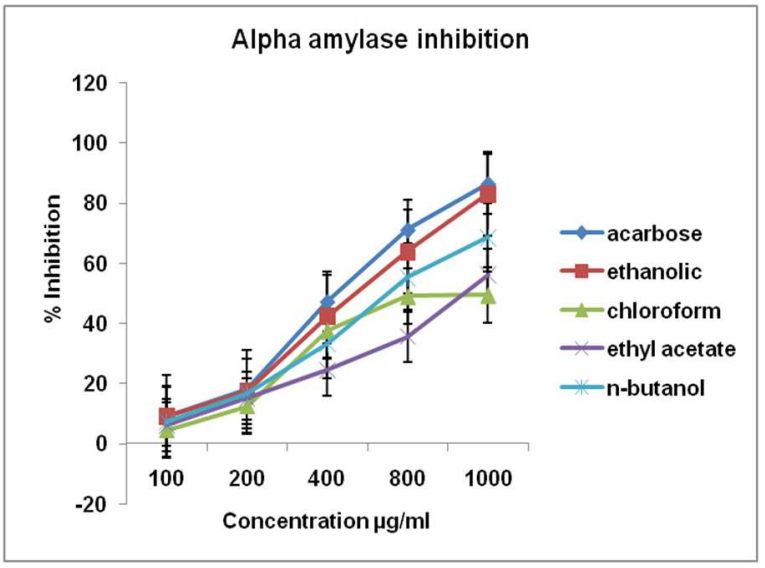

Fig. 1: In vitro inhibition of $\alpha$-amylase enzyme by various extracts of leaves of Ficus semicordata. The results represents the mean $\pm \operatorname{SEM}(n=3)$

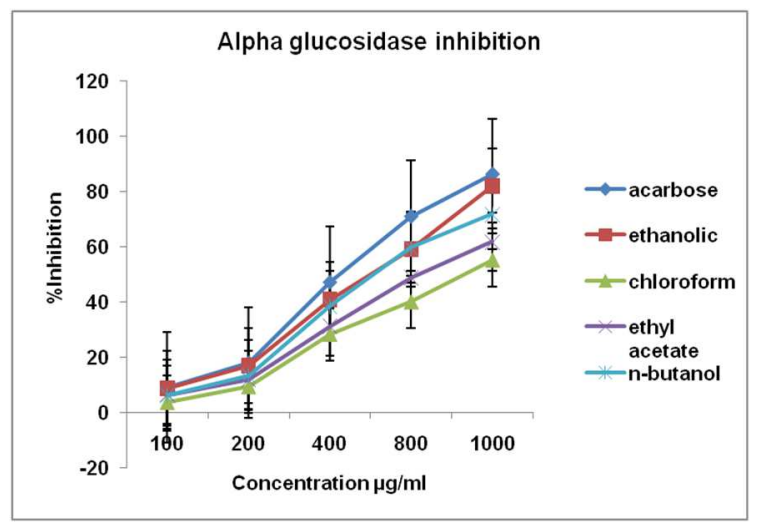

Fig. 2: In vitro inhibition of $\alpha$-glucosidase enzyme by various extracts of leaves of Ficus semicordata. The results represents the mean $\pm \operatorname{SEM}(n=3)$

Table 1: IC $C_{50}$ value of $\alpha$-amylase and $\alpha$-glucosidase enzyme inhibition by various extracts of Ficus semicordata

\begin{tabular}{lll}
\hline Plant extract & \multicolumn{2}{l}{ Inhibitory concentration $\mathbf{I C}_{\mathbf{5 0}}(\boldsymbol{\mu g} \mathbf{g} \mathbf{m l})$} \\
\cline { 2 - 3 } & $\boldsymbol{\alpha}$-Amylase & $\boldsymbol{\alpha}$-Glucosidase \\
\hline Acarbose & $3.175 \pm 0.01$ & $3.175 \pm 0.01$ \\
Ethanolic & $3.352 \pm 0.03$ & $3.448 \pm 0.24$ \\
Chloroform & $4.540 \pm 0.22$ & $4.707 \pm 0.35$ \\
Ethyl Acetate & $4.861 \pm 0.41$ & $4.226 \pm 0.43$ \\
N-Butanol & $3.86 \pm 0.35$ & $3.686 \pm 0.11$ \\
\hline
\end{tabular}

The values are expressed as mean \pm SEM $(n=3)$

\section{Identification of compounds isolated by column chromate- graphy from Ficus semicordata}

Compound FS-1 Elution of the column with n-hexane: dichloromethane (8:2) fraction no. F3, F4 was obtained as a yellow powder that after recrystallization with methanol formed an amorphous yellow powder. Yield $=475 \mathrm{mg}, \mathrm{M} . \mathrm{P}=215-217{ }^{\circ} \mathrm{C} \mathrm{R}_{\mathrm{f}}=: 0.67$, [toluene (5): ethyl acetate (4): formic acid (1)] IR: (KBr, vmax, cm1): 3400 (O-H stretching vibration of phenol-OH), 3021.77 (C-H stretching of aromatics), 1718.64 ( $\mathrm{C}=0$ stretching vibration-OC=0),), 1602.26 ( $\mathrm{C}=\mathrm{C}$ stretching vibration, alkene), 1467 1425, 1215 (C-OH stretching vibration, phenol-OH), 1262 (C-O-C), 928.22, $763.96,671.08,627$ (C-H out of plane bending of aromatic hydrocarbon).

Mass m/z: 301[M+] $\left(\mathrm{C}_{15} \mathrm{H}_{10} \mathrm{O}_{7}\right),\left({ }^{1} \mathrm{HNMR}\right): \delta 7.728(1 \mathrm{H}, \mathrm{H}-6, \mathrm{~s}), 7.721$ (1H, H-8, s), 7.639 (1H, H-2', s), 7.632 (1H, H-5', s), 6.895 (1H, H-6', s), $6.885(1 \mathrm{H}, \mathrm{H}-3), 6.382(1 \mathrm{H}, \mathrm{H}-7, \mathrm{~s}), 6.180(\mathrm{H}-5, \mathrm{~s})$ and $4.997(1 \mathrm{H}$, H-3', 4', s).
Conclusion: On the basis of spectral evidence of compound FS-1 was established as Quercetin.

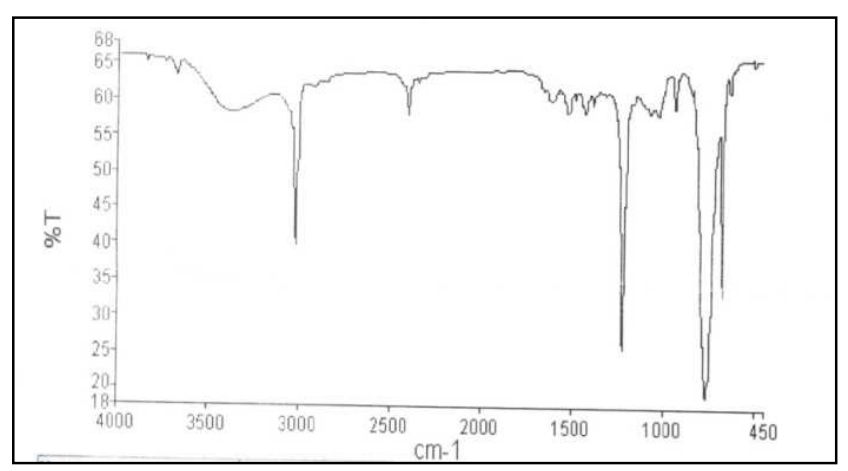

Fig. 3: FTIR spectrum of compound FS-1 


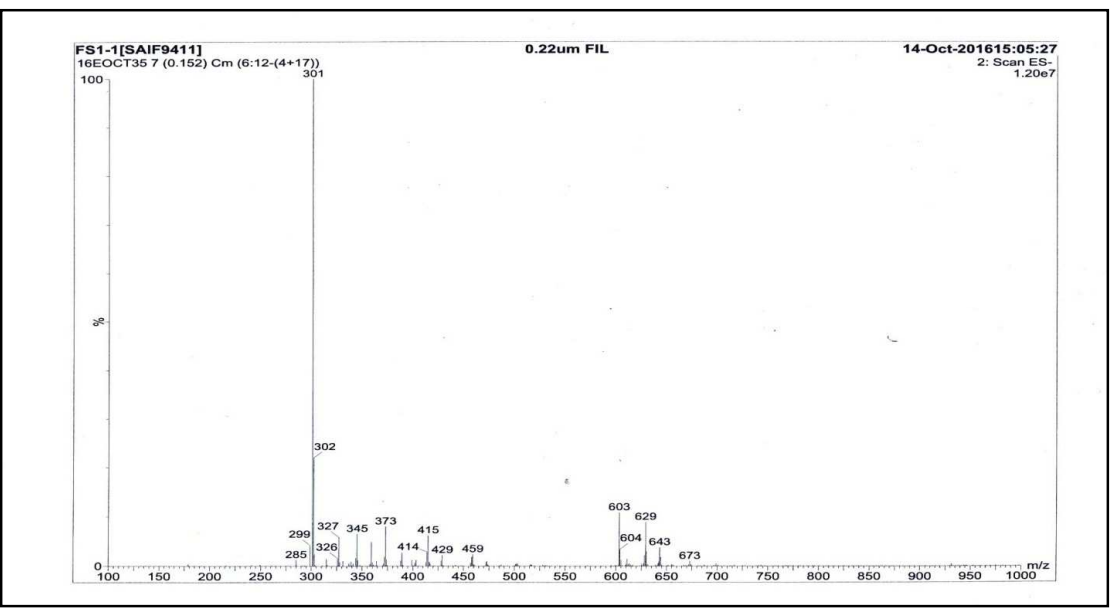

Fig. 4: Mass spectrum of compound FS-1

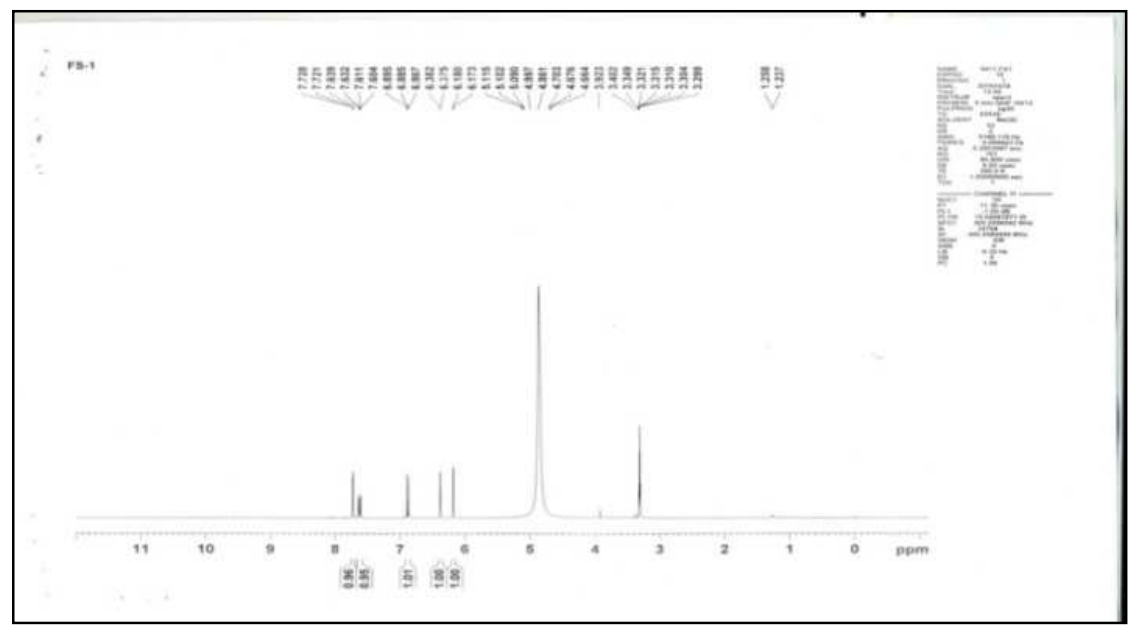

Fig. 5: ${ }^{1} \mathrm{H}-\mathrm{NMR}$ spectrum of compound FS-1<smiles>CC(O)C(O)C#N</smiles>

QUERCETIN
Compound FS-2 Elution of the column with ethyl acetate: methanol (9:1) fraction no. F11-F12 was obtained as a white powder that after recrystallization with methanol formed an amorphous white powder. Yield $=360 \mathrm{mg}, \mathrm{M} . \mathrm{P}=235-237^{\circ} \mathrm{C}, \mathrm{R}_{\mathrm{f}}=: 0.64$ [toluene (4): ethyl acetate (3): methanol (3)]. IR: (KBr, vmax, cm-1): 3369.46 (O$\mathrm{H}), 3019.82,2400.23$ (OH carboxylic acids) 1603.66 (C=C alkene) 1215.63 (C-O alcohol), 1023.66, 929.01, 756.94, 669.33 (C-H out of plane bending of aromatic hydrocarbon). Mass $\mathrm{m} / \mathrm{z}: 169\left[\mathrm{M}^{+}\right]$ $\left(\mathrm{C}_{7} \mathrm{H}_{6} \mathrm{O}_{5}\right),{ }^{1} \mathrm{HNMR} \delta 7.128(1 \mathrm{H}, \mathrm{H}-2, \mathrm{H}-6, \mathrm{~s})$ and $5.3(1 \mathrm{H}, \mathrm{H}-3, \mathrm{H}-4, \mathrm{H}-5$, s). Conclusion: On the basis of spectral evidence of compound FS-2 was established as Gallic acid.

Fig. 6: Quercetin

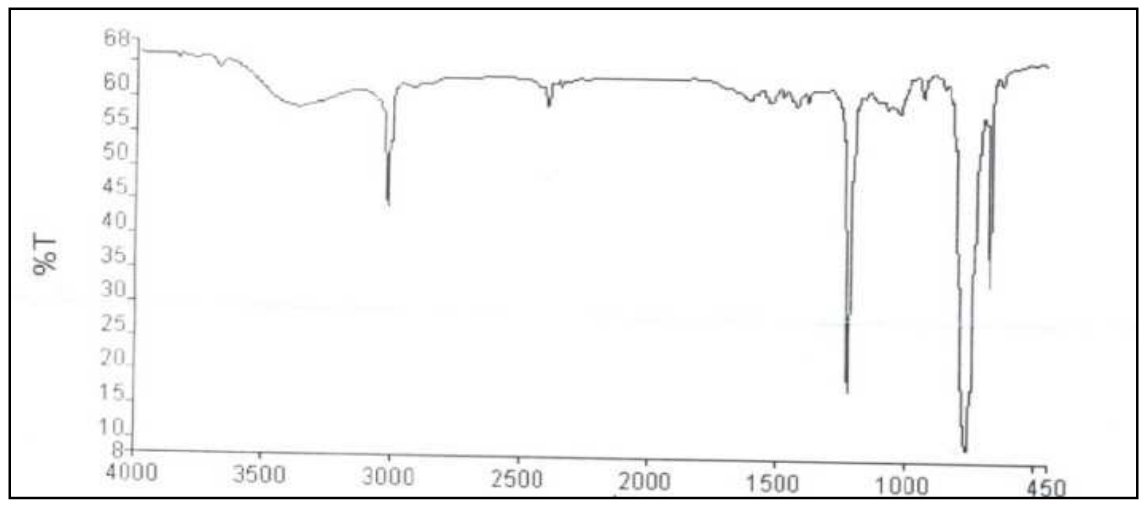

Fig. 7: FTIR spectrum of compound FS-2 


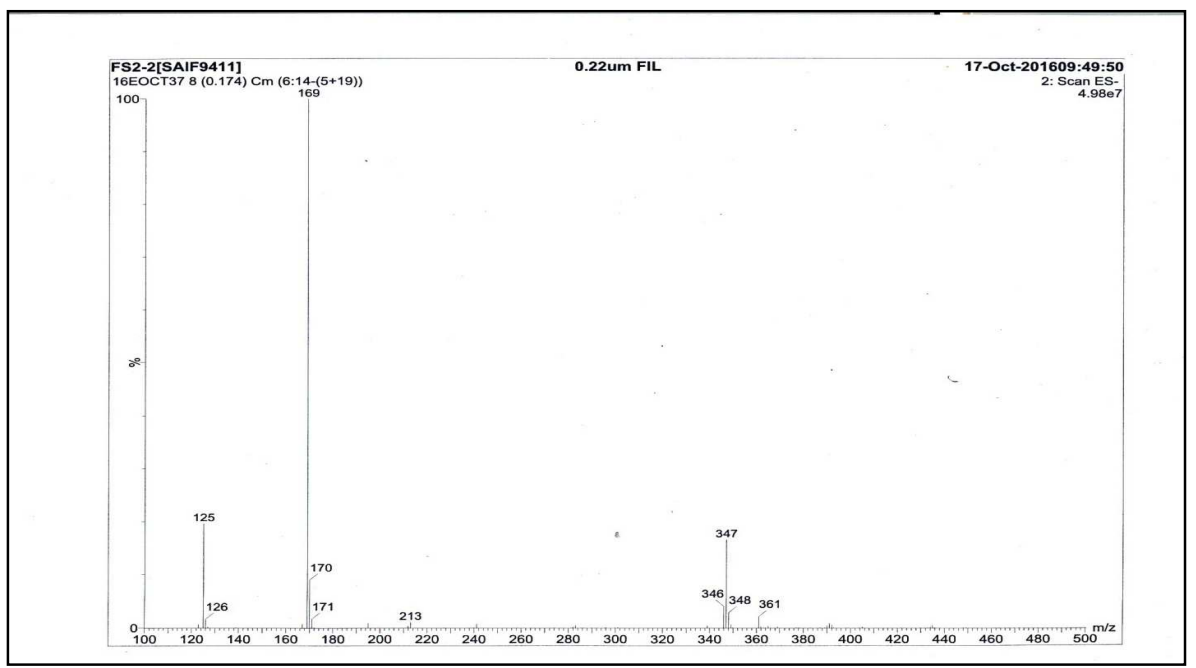

Fig. 8: Mass spectrum of compound FS-2

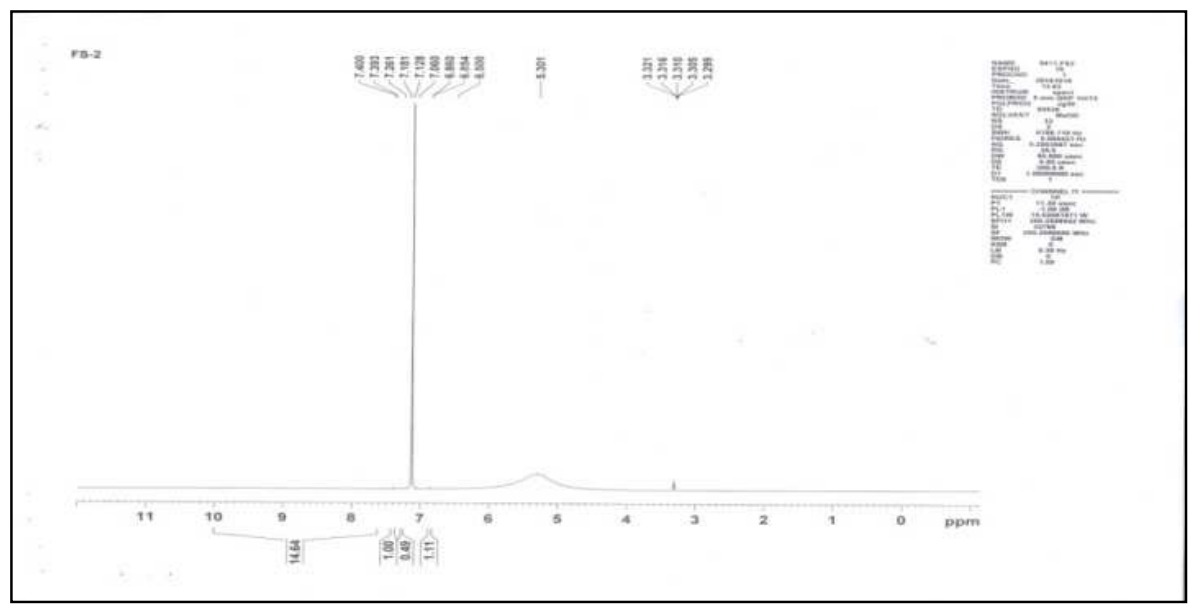

Fig. 9: ${ }^{1} \mathrm{H}-\mathrm{NMR}$ spectrum of compound FS-2<smiles>O=C(O)c1cc(O)c(O)c(O)c1</smiles>

GALLIC ACID

Fig. 10: Gallic acid

\section{Acute toxicity studies}

Acute toxicity study revealed the non-toxic nature of compounds of FS. No mortality was observed in the compounds treated rats and the behaviour of the treated rats appeared normal. There was no mortality or toxic reaction found at any dose selected until the end of the study.

\section{In vivo antidiabetic study}

\section{Effect of FS-1, FS-2 on blood glucose level of hyperglycemic rats}

The results illustrated in fig. 11 reveals that the effect of compounds FS-1, FS-2 on fasting blood glucose level in normal and experimental animals at the end of 21st d of the study. In the diabetic control group, the fasting blood glucose level was consistently high throughout the study and was significantly increased $(* * \mathrm{p}<0.05)$ when compared to normal rats. Oral administration of FS-1, FS-2 (50 $\mathrm{mg} / \mathrm{kg} \mathrm{b.} \mathrm{w)} \mathrm{and} \mathrm{glibenclamide} \mathrm{(30} \mathrm{mg/kg} \mathrm{b.} \mathrm{w)} \mathrm{to} \mathrm{diabetic} \mathrm{rats}$ significantly decreased $\left({ }^{*} \mathrm{p}<0.05, \quad{ }^{* *} \mathrm{p}<0.01, \quad{ }^{* * *} \mathrm{p}<0.001\right)$ blood glucose levels. In the FS-1, FS-2 treated groups, although a significant anti-hyperglycemic effect was evident from 14th d onwards, a significant decrease in blood glucose was maximum at the end of the 21st d.

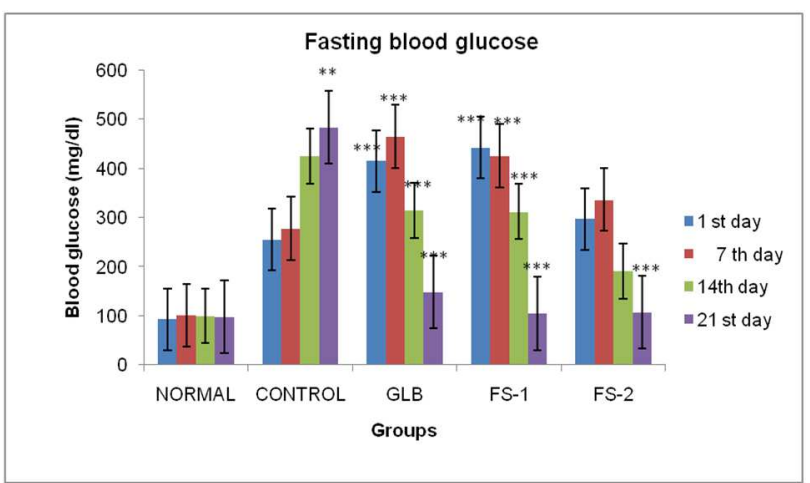

Fig. 11: Effect of isolates FS-1, FS-2 and standard antidiabetic drug, glibenclamide (GLB) on fasting blood glucose (mg/dl) levels in STZ induced diabetic rats. Each bar represented the mean $\pm \operatorname{SEM}(n=6)$ and analyzed for Newman Keul's test significant at $\left({ }^{*} \mathbf{p}<0.05, * * \mathbf{p}<0.01,{ }^{* * *} \mathbf{p}<0.001\right)$ when compared with diabetic control group 


\section{Effect on body weight}

Rats showed a marked decrease in body weight after STZ (50 mg/kg, i. p. injection). Healthy rats were found to be stable in their body weight, but diabetic rats showed a significant reduction in body weight during $21 \mathrm{~d}$ [fig. 12]. This fall in body weight was successfully antagonized by the compounds FS-1, FS-2 treatment.

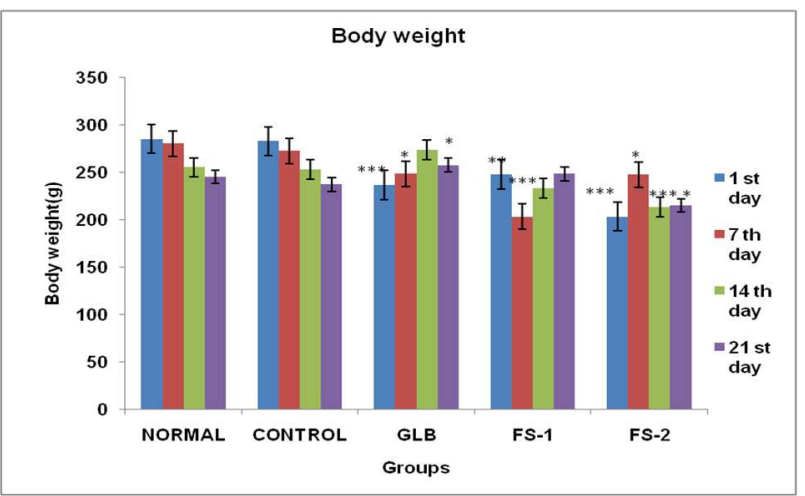

Fig. 12: Effect of isolates FS-1, FS-2 and standard antidiabetic drug, glibenclamide (GLB) on changes in body weight (g) in STZ induced diabetic rats. Each bar represents the mean $\pm \operatorname{SEM}(n=6)$ and analyzed for Newman Keul's test significant at $\left({ }^{*} p<0.05, * * p<0.01\right.$, $\left.{ }^{* * *} \mathbf{p}<0.001\right)$ when compared with diabetic control group

\section{Effect on water intake, food intake and urine output}

The untreated diabetic control rats had severe polyphagia and polyuria by the end of the experimental period. Fig. 13, 14 and 15 illustrates that diabetic control rats showed higher intake of food and water and urine output when compared with normal control groups.

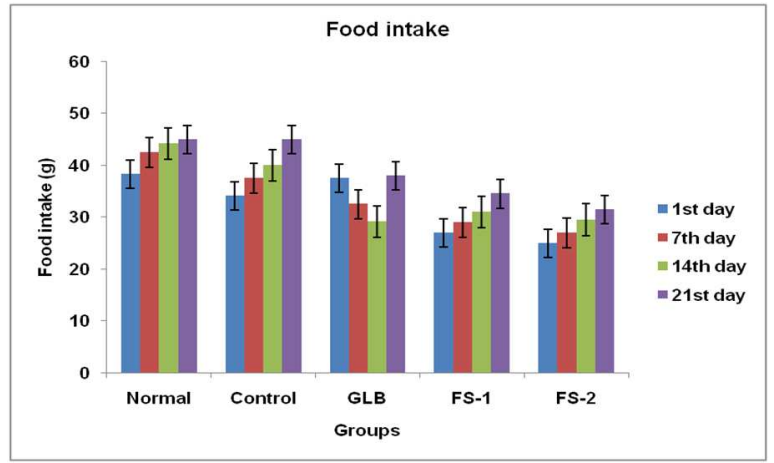

Fig. 13: Effect of isolates FS-1, FS-2 and standard antidiabetic drug, glibenclamide (GLB) on food intake (g) in STZ induced diabetic rats. Each bar represents the mean $\pm \operatorname{SEM}(n=6)$.

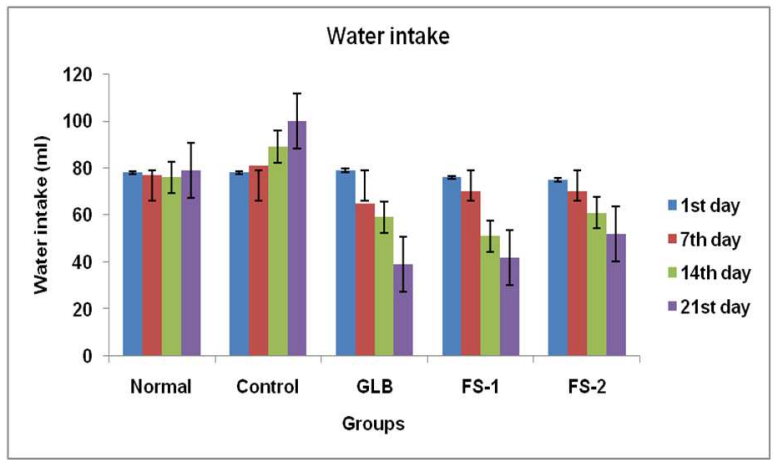

Fig. 14: Effect of isolates FS-1, FS-2 and standard antidiabetic drug, glibenclamide (GLB) on water intake in STZ induced diabetic rats. Each bar represents the mean $\pm \operatorname{SEM}(n=6)$.
The food and water intake and urine output were decreased in diabetic rats treated with both isolated compounds and glibenclamide. The effect of compound FS-1, FS-2 at the tested dose levels, considerably reduced food and water intake and urine output of hyperglycemic rats in comparison to the diabetic control group by the end of the $21^{\text {st }} \mathrm{d}$.

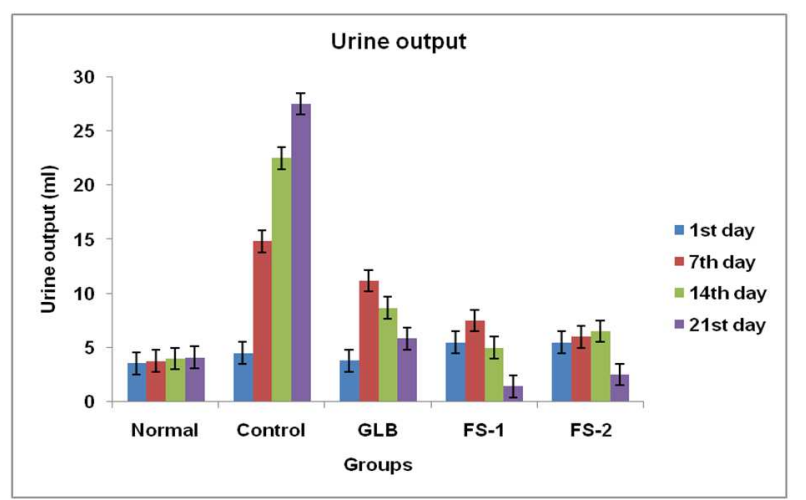

Fig. 15: Effect of isolates FS-1, FS-2 and standard antidiabetic drug, glibenclamide (GLB) on urine output in STZ induced diabetic rats. Each bar represents the mean $\pm \operatorname{SEM}(n=6)$.

\section{DISCUSSION}

Postprandial hyperglycemia is the key problem in diabetes mellitus [21]. One of the therapeutic approaches is to decrease the postprandial rise in blood glucose by inhibiting key enzymes hydrolyzing the dietary carbohydrates [22, 23]. Alpha-amylase is secreted by the pancreas and the salivary glands. It is a key enzyme in the carbohydrate digestion which catalyses the initial hydrolysis of starch by acting on the interior alpha-D-1, 4 glucosidic linkages. Amylase converts starch into alpha-limit dextrins, maltose, and maltotriose [24]. The enzyme alpha-glucosidase present in the epithelial mucosa of the small intestine is an important enzyme; those catalyze the final step in the digestive process of carbohydrates i.e. conversion of polysaccharide to monosaccharide which is absorbed through the intestine. Inhibition of alpha-amylase and alphaglucosidase can slow the uptake of dietary carbohydrates and suppress postprandial hyperglycemia [25]. Synthetic inhibitors show gastrointestinal side effects such as bloating, abdominal discomfort, diarrhea, and flatulence making them less attractive as therapeutic agents [26]. The present study was conducted to investigate the potential inhibitory effects of Ficus semicordata on the major carbohydrate hydrolyzing enzymes; alpha amylase and alphaglucosidase. Five different concentrations were tested; the extract showed a good inhibitory effect at all the tested concentrations $(100$ $200,400,800,1000 \mu \mathrm{g} / \mathrm{ml}$ ). Acarbose enzyme was used as a standard for various concentrations. The results of the study indicate that $F$. semicordata have strong inhibitory effects on alpha amylase and an alpha-glucosidase activity even at a very low concentration of extracts [fig. 1, 2]. F. semicordata ethanolic extract showed a very high inhibitory activity against alpha amylase $\left(\mathrm{IC}_{50} 3.352 \mu \mathrm{g} / \mathrm{ml}\right)$ and alphaglucosidase ( $\mathrm{IC}_{50} 3.448 \mu \mathrm{g} / \mathrm{ml}$ ) as compared to standard drug acarbose [table 1]. The reaction mechanism involved in inhibition of alphaamylase and alpha-glucosidase by plant polyphenols such as flavonoids and terpenoids which might cause conformational changes in enzyme structure $[25,26]$.

The present study was also undertaken to access the in vivo antihyperglycemic activity of the compounds isolated from leaves of Ficus semicordata. The ethanol extract of the leaves of Ficus semicordata has displayed high alpha-glucosidase and alphaamylase inhibitory effects through investigations. Thus the plant has been proven to have anti-hyperglycemic properties. In all diabetic patients, treatment should aim to lower blood glucose to near normal levels. The present investigation fulfills this statement by producing significant fall in blood glucose levels especially seen in rats treated with Ficus semicordata. Compounds FS-1 and FS-2 
isolated from Ficus semicordata at doses of $50 \mathrm{mg} / \mathrm{kg}$ showed a significant effect on the glucose tolerance of rats, thus revealing the hyperglycemic nature of the compounds. The effect of the compounds was compared to that of diabetic control and reference standard, glibenclamide and was found to be statistically significant $\left({ }^{*} \mathrm{p}<0.05,{ }^{* *} \mathrm{p}<0.01,{ }^{* * *} \mathrm{p}<0.001\right)$.

Induction of diabetes with STZ is associated with a characteristic loss of body weight which is due to increased muscle wasting and loss of tissue proteins [26-29]. Diabetic rats treated with compounds isolated from Ficus semicordata showed significantly $(\mathrm{p}<0.05,0.001)$ increase in body weight as compared to diabetic control, which may be due to its effect in controlling muscle wasting (i. e by reversal of gluconeogenesis and glycogenolysis) and may also be due to improvement in insulin secretion and glycemic control [26-31]. The other parameters like food intake and water intake, urine output affected due to hyperglycemia were significantly reversed to normal by drug treatment as shown in fig. 13, 14, 15.

\section{CONCLUSION}

The present study indicated that the ethanolic extract of Ficus semicordata has a high amount of phenolic and flavonoid contents. The antidiabetic activity of the plant is correlated with the phenolic and flavonoid contents. The results of the present study suggest that Ficus semicordata leaves ethanolic extract and its bioactive subfractions (FS-1, FS-2) possess potent glucose lowering effect. Thus, in diabetes mellitus, FS- 1 and FS- 2 might be able to increase the sensitivity to insulin, rather than increasing insulin secretion. The mechanism which may be involved in this process would be possibly by increasing the number or raising the sensitivity of insulin receptor site to insulin. As a result, it increases the uptake of glucose, consequently leading to a reduction of glucose level. Hence, the extract and the subfractions of $F$. semicordata represent the source of potential antidiabetics that can be used in pharmaceutical industry.

\section{ACKNOWLEDGEMENT}

The authors are thankful to Sophisticated Analytical Instrument Facility, CDRI Lucknow for providing the spectra of the pure compounds.

\section{CONFLICT OF INTERESTS}

\section{Declared none}

\section{REFERENCES}

1. Grover JK, Yadav S, Vats V. Medicinal plants of India with antidiabetic potential. J Ethnopharmacol 2002;81:81-100.

2. Fabricant DS, Farnsworth NR. The value of plants used in traditional medicine for drug discovery. Environ Health Perspect 2001;109:69-75.

3. Houghton PJ. Synergy and polyvalence: a paradigm to explain the activity of herbal products. Evaluation of herbal medicinal products. London: London Pharmaceutical Press; 2009.

4. Riyal Bardia National Park, Nepal. ZSL conservation report no. 3. Edited by S. Oliver. London: The Zoological Society of London; 2005. p. 119.

5. Karki L. Documentation of indigenous knowledge on the utilization of plant resource by the chepang community in dhading district, Nepal. Central Department of Botany, Tribhuvan University; 2001. p. 106.

6. Chaudhary RP, Joshi RM, Budha P, Kunwar RM, Makalu Barun. Landscape project (Biodiversity component). Nepal Biodiversity Landscape Project, Kathmandu, Nepal; 2001. p. 87.

7. Panthi MP, Chaudhary RP. Angiosperm flora of Arghakhanchi district and adjoining areas, West Nepal. J Nat History Museum 2002;21(Suppl 1-4):7-32.

8. Bhattarai GP. Diversity and indigenous uses of flowering plant resources in the churiya forests of parsa wildlife reserve and adjoining areas. Central Department of Botany, Tribhuvan University; 2002. p. 110.

9. Mueller-Boker U. Ethnobotanical studies among the Chitwan Tharu. J Nepal Res Centre 1993;9:17-56.
10. Singh HB, Singh RS, Sandhu JS. Herbal medicine of Manipur: a color encyclopedia. 1st ed. New Delhi: Daya publishing house; 2003.

11. Khumbongmayum AD, Khan ML, Tripathi RS. Ethnomedicinal plants in the sacred groves of Manipur. Indian J Traditional Knowledge 2005;4:21-3.

12. Rayakala KV, Ali SS, Sharanabasava H, Sharma P, Bora U. Ethnobotany of plants used to cure diabetes by people of Northeast India. Med Aromatic Plants Sci Biotechnol 2009;4:64-8.

13. Nair SS, Kavrekar V, Mishra A. In vitro studies on alpha amylase and alpha-glucosidase inhibitory activities of selected plant extract. Eur J Exp Biol 2013;3:128-32.

14. Sudha P, Zinjarde SS, Bhargava SY, Kumar AR. The potent $\alpha$ amylase inhibitory activity of Indian Ayurvedic medicinal plants. BMC Complementary Altern Med 2011;11:5.

15. Pistia-Brueggeman G, Hollingsworth RI. A preparation and screening strategy for glycosidase inhibitors. Tetrahedron 2001; 57:8773-8.

16. Ecobichon DJ. The basis of toxicology testing. New York: RC Press; 1997.

17. Brosky G, Logothetopoulos J. Streptozotocin diabetes in the mouse and guinea pig. Diabetes 1969;18:606-11.

18. Kumar A, Ilavarasan R, Jayachandran T, Deecaraman M, Aravindan P, Padmanabhan N, et al. the Anti-diabetic activity of Syzygium cumini and its isolated compound against streptozotocin-induced diabetic rats. J Med Plants Res 2008;2:246-9.

19. Ghosh MN. Fundamentals of experimental pharmacology. 2nd ed. Calcutta: Calcutta Scientific Book Agency; 1984.

20. Kulkarni SK. Handbook of Experimental Pharmacology. III ed. Delhi: Vallabh Prakashan; 1999.

21. Samyal ML, Ahuja A, Ahmed Z. Estimation of antihyperglycemic and antihyperlipidemic activity of isolated fractions from Ficus glomerata bark extract in streptozotocin-induced diabetic rats. UK J Pharm Biosci 2014;2:43-8.

22. Poongunran J, Perera HK, Fernando WIT, Jayasinghe L, Sivakanesan. $\alpha$-Glucosidase and $\alpha$-amylase inhibitory activities of R. Nine Sri Lankan Antidiabetic Plants. Br J Pharm Res 2015;7:365-74.

23. Shareef MI, Reddy PJM, Gopinath SM, Dayananda KS, Mandal A. In vitro $\alpha$-amylase inhibitory activity of the leaves of Tinospora cordifolia. Int J Innovative Res Sci Eng Technol 2014;3:10091-6.

24. Ou S, Kwok K, Li Y, Fu L. In vitro study of the possible role of dietary fiber in lowering postprandial serum glucose. J Agric Food Chem 2001;49:1026-9.

25. Vennila V, Pavithra V. In vitro alpha amylase and alphaglucosidase inhibitory activity of various solvent extracts of Hybanthus Enneaspermus Linn. World J Pharm Pharm Sci 2015;4:1425-37.

26. Singh NP, Kar DM, Shweta P. Antidiabetic activity and modulation of antioxidant status by fractions of Argemone mexicana in alloxan induced diabetic rats. Int J Green Pharm 2012;6:321-9.

27. Rout Soumya P, Kar Durga M, Mohapatra Santosh B, Swain Sharada P. Anti-hyperglycemic effect Annona reticulata 1. Leaves on an experimental diabetic rat model. Asian J Pharm Clin Res 2013;6(Suppl1):56-6.

28. Pepato MT, Folgado VBB, Kettelhut IC, Brunetti IL. Lack of antidiabetic effect of a Eugenia jambolana leaf decoction on rat streptozotocin diabetes. Braz J Med Biol Res 2001;34:389-95.

29. Mujeeb M, Khan AK, Ali M, Mall A, Ahmad A. Antidiabetic activity of the aqueous extract of Chlorophytum borivilianum in streptozotocin-induced hyperglycemic rats. J Pharm Res 2009;2:51-3.

30. Bashir MK, Ismail S, Ma HQ Abdullah NH, Abas Hussain HJ. The in vitro and ex vivo effect of Phyllanthus niruri methanol extract on hepatic glutathione s-transferase activity in STZ induced diabetic sprague dawley rats. Asian J Pharm Clin Res 2015;8:156-9.

\section{How to cite this article}

Virender Kaur, Kumud Upadhyaya, Milind Pande. Bioassay-guided evaluation of Ficus semicordata for antidiabetic activity. Int J Pharm Pharm Sci 2017;9(3):71-77. 